\section{The Idea of the Service University}

\section{Arild Tjeldvoll}

Arild Tieldvoll is professor of education at the University of Oslo, Norway. Address: Institute of Educational Research, University of Oslo, POB 1093, N-0317 Oslo, Norway. E-mail: <arild.tjeldvoll@ped.vio.no>.

$\mathrm{T}$ he "service university" as a university model is increasingly debated internationally. The most salient characteristic is its similarity with a market-driven enterprise. To survive, a service university has to develop products that are competitive in a knowledge market. According to the research literature, the internal and external factors pushing a university in the service direction are: ideological changes, the current state of scientific knowledge, the students, the administration, and the state. University development in the service direction has been particularly strong in Australia, New Zealand, Canada, the United States, and the United Kingdom, but the trend is global and has also reached the shores of Scandinavia. The universities of Oslo and Stockholm both exhibit policies in accordance with the international trend. However, the development is more pronounced in Stockholm than in Oslo. Sweden is fighting its way out of a recession, and has to develop more efficient knowledge production and goaleffective higher education. Norway, with an affluent oil economy, is developing in a more relaxed way. In the rest of Europe the situation varies. While the University of Twente in the Netherlands can be seen as a prototype of a successful service university, universities in both Germany and France seem to be moving more slowly in their market orientation.

\section{To survive, a service university has to develop products that are competitive in a knowledge market.}

The trademark of a research university-independent production of scientific knowledge-is obviously challenged by the service university model. In the wake of postmodernism and the critique of positivism, the earlier division of knowledge into distinct disciplines is no longer generally accepted. The university's monopoly on knowledge production is under challenge by several external agents-specialized research sites, frequently labeled "mode- 2 production of knowledge." The quantitative success of universal higher education creates teaching quality problems for the university. The qualitative success produces numerous well-qualified graduates who return to society as researchers, in jobs where they compete with their alma mater in knowledge production. The end of the cold war implied a clear ideological victory for the liberal market economy as an overall paradigm for society. It has become increasingly difficult for the state to cope with public expenditures. The welfare state is eroding, and the state has become an increasingly unfaithful patron for the university. Hence the public research university finds itself in the unusual situation of being forced to take direct and major responsibility for its budgets. It is forced to become entrepreneurial in order to stay in business.

\section{The university's monopoly on knowl- edge production is under challenge by several external agents.}

Serving society is nothing new for the university. Indeed, such service has historically been its overall mission. The rise of the service university model is particularly dramatic in the public university's changed relationship to the state, which has possible consequences for its institutional autonomy and academic freedom. Trying to imagine future consequences for the university from the current service development, three possible scenarios come to mind.

\section{The Degenerating Service University}

In this scenario, the university, through its professors and administration, is unable to convince the state patron of the rational and democratic necessity of giving sufficient public funding to attract and keep professors for high-quality teaching and independent research. The university is neither able to compete successfully for research grants from public and independent foundations, nor to find new sources of funding in the higher education and applied research markets. Gradually, this institution will likely be forced to recruit a less-qualified staff. In the competition for fee-paying students, it will most likely recruit students with fewer academic qualifications and lower fee-paying capacity. This university will most likely fall into a vicious circle, degenerating into a school of low quality and reputation, at the risk of being closed down.

\section{The Service University Supermarket}

The second scenario envisions a research university transformed by the principles of a business enterprise. Research policies and curricula of this institution are 
designed to be competitive with other higher education institutions in meeting the needs expressed by private business and public bureaucrats. Teaching programs will typically consist of tailor-made short courses demanded by business clients and professional studies required by the state. All research will be applied research responding to the information needs of the public and private market. There will be no tenured positions and hardly any need for philosophers, sociologists, or critical political scientists and economists. Most staff will be parttime or specialists under contract. The university leadership and administration will have similar competencies as successful business corporations.

\section{The Academic Service University}

In this scenario, the university has acknowledged the new ideological and financial reality-in particular, the unfaithfulness of the state. Unlike the "degenerating university," it has succeeded in finding other funding sources. It has been able to maintain the best possible relations with the state as an on-going important client. It has also successfully competed for the research programs offered by foundations and been able to identify niches in the market for its research and education products. By its own initiatives, it has achieved financial independence. It is able to produce competitive revenue-generating services for public and private clients, resulting in a budget that makes it possible to sustain independent research and educational policies and programs. Different from the "supermarket university," it consciously uses its budget to keep up with international academic standards. Teaching programs in the arts and sciences are maintained, and its researchers are free to carry out critical research on the state bureaucracy and corporate life. Professors' salaries are decent and competitive, signaling a continued high social status for research and higher education. The "academic service university" has been able to strike a balance between individual academic freedom, institutional autonomy, and accountability toward taxpayers and business. At the same time as it is serving these clients, it is creating the financial independence that enables it to carry out its critical function in a democratic society.

\section{Research on the Service University}

At present there is an international network of 14 universities in 10 countries attempting to produce case studies of the level and character of service university development in their countries. At the Oslo and Stockholm universities specific projects concerning the relationship between the university and its clients, university leadership, budgeting, the role of professors and continuing education-in a comparative perspectiveare ongoing.

\section{Linking Funding, Student Fees, and Student Aid: An Alternative to Cost Recovery}

\section{Arthur M. Hauptman}

Arthur Hauptman is a prominent consultant and author specializing in higher education finance and public policy issues. He has taught in the higher education program at Boston College, and has worked recently in Jordan on issues of cost recovery in higher education. E-mail: $<$ hauptman@erols.com>.

$\mathrm{I}$ $\mathrm{n}$ the past quarter century, most developed and developing countries around the world have moved toward a system of financing higher education that is based on the principle of cost recovery. Under a cost recovery approach, tuition fees are set as a proportion-typically less than half-of the educational cost per student. Most or all of the remaining costs per student are then covered by government funding.

Cost recovery represents a significant improvement over the process it replaced in most countries where government allocations were largely based on the political strength of the institution. Fees were low or zero reflecting the philosophy that higher education is strictly a public good. One problem with the low or no tuition fee approach, however, is that it fails to reflect the private benefits college students receive in the form of higher incomes by virtue of their college attendance and graduation. In addition, a minimal tuition fee strategy may result in lower levels of college participation if it is combined with relatively low levels of government support for higher education. Cost recovery addresses these problems by increasing student fees to more nearly reflect the private benefits that students receive and by increasing resources devoted to higher education.

But for all of its advantages, cost recovery creates its own set of problems. For instance, the procedures tend to encourage institutions to raise funds privately and build these funds into their expenditure base as a means for increasing the revenues they receive from student fees. For this reason, cost recovery creates incentives for institutions to increase their costs rather than moderate them. Similarly, setting fees as a percentage of costs per student may encourage institutions to restrict their enrollmentsthereby increasing their costs per student-and thus possibly augmenting the public revenues they receive. In short, cost recovery can lead to higher costs per student and less access.

Another criticism of cost recovery is that it tends to reinforce the inequities already existing in a country's higher education structure. Under cost recovery, institutions with high levels of resources per student tend to receive the most 